九州大学学術情報リポジトリ

Kyushu University Institutional Repository

\title{
Analys is of IS0-Tank Wall Physical Exergy Characteristic : Case Study of LNG Boil-off Rate from Retrofitted Dual Fuel Engine Conversion
}

Pamitran, Agus Sunjarianto

Mechanical Engineering Department, Faculty of Engineering, University of Indonesia

Budiyanto, Muhammad Arif

Mechanical Engineering Department, Faculty of Engineering, University of Indonesia

Maynardi, R. Dandy Yusuf

Mechanical Engineering Department, Faculty of Engineering, University of Indonesia

https://doi.org/10.5109/2321007

出版情報 : Evergreen. 6 (2)，pp.134-142，2019-06. 九州大学グリーンテクノロジー研究教育センター バージョン：

権利関係 : 


\title{
Analysis of ISO-Tank Wall Physical Exergy Characteristic - Case Study of LNG Boil-off Rate from Retrofitted Dual Fuel Engine Conversion
}

\author{
Agus Sunjarianto Pamitran *, Muhammad Arif Budiyanto, R. Dandy Yusuf Maynardi
}

Mechanical Engineering Dept., Faculty of Engineering, University of Indonesia, Depok 16424, West Java, Indonesia

*Author to whom correspondence should be addressed,

E-mail: pamitran@eng.ui.ac.id

(Received March 8, 2019; accepted March 26, 2019)

\begin{abstract}
Ministry of Transportation of the Republic of Indonesia has conducted a feasibility study for conversion plans with the use of $60 \%$ LNG fuel on its 3200 DWT passenger ship using LNG ISOtank type T75 size 20 feet (1 TEU), but only limited to economical study. To verify that the conversion plan is really profitable, analysis of physical exergy characteristics i.e. the rate of exergy transfer and destruction through tank wall due to heat transfer, boil-off rate and boil-off gas from stored LNG is conducted by a closed system exergy balance approach with specified shipping conditions parameters, using the empirical equations of the literature and physical model of the three tank options offered, designed using COMSOL Multiphysics 5.1. The results show a positive correlation between exergy destruction rate with BOR and BOG values, depending on the total thermal resistance value $R_{\text {tot }}$ due to material variation of shell and insulation of tank wall affecting the value of heat leak on the inner and outer surface of the tank wall. Quality scale is presented to summarize the analysis parameters that can be measured by cost, i.e. the exergy cost and operating costs required by forced vaporizer to achieve the required BOR.
\end{abstract}

Keywords: dual fuel, retrofit, LNG, heat leak, physical exergy, exergy transfer. exergy destruction, boil-off gas, ISO-tank.

\section{Introduction}

In the case of ships using liquefied natural gas fuel, either partially or completely, the amount of Boil-off Gas (BOG) is indicated by Boil-off Rate (BOR) depending on the specification of the existing storage system and environment [1]. The process of evaporation of LNG into gas phase indicates the existence of ongoing thermodynamic process, it is necessary to find relation with characteristic of exergy movement through wall of ISO-tank tank in question [2]. In general, a ship which used gas evaporation of LNG specially designed with highly insulated storage tanks, this matter is used to avoid evaporation of the valuable cargo during a transportation $[3,4]$. The storage of evaporation gas from LNG commonly use of ISO-Tank, some portion will vaporize on the liquid surface of the cargo, producing boiloff gas (BOG) [5]. The amount of BOG will increase when the pressure level of the storage tanks and thus the mechanical stress of the structure [6].

Simply put, the liquefied natural gas stored in ISO-tanks has exergy accompanying heat transfer but does not yet have exergy accompanying work because it has not been used [7]. Given that exergy or available energy can be lost or destroyed so that it cannot be used, it can be deduced that the greater the BOR will be the greater the possibility of a large energy loss [8]. In order to remove or utilize the BOG from the ISO-tank, the main engine of the ship with steam turbine propulsion systems have been widely used $[9,10$, 11]. The unused BOG is burned in boilers to produce steam, which is fed to steam turbine system and turbo generators then, in the end, will supply propulsion and electric power $[12,13]$. In the other hand, the ship propulsion with steam turbine system has a lower thermal efficiency compared to heavy fuel oil (HFO) diesel engines, which is the main propulsion system of common cargo ships $[14,15]$. In addition, steam turbine system has disadvantages in the need high improved insulation technologies for ISO-tanks and a large amount of carbon dioxide in the exhaust gas from the boiler. Thus, the selection of the insulation type of ISOtanks for the BOG is important issues in the use of Dual Fuel Engine Conversion. 
Ministry of Transportation of the Republic of Indonesia via X Company has selected one type of ISO-tank type T75 as LNG storage, and also 2 other T75 tank options to consider, which will then be ordered if it is declared more effective and efficient, both technically and economically in the long run. The exergy analysis in the LNG fuel storage tank on board is done to provide a choice of specification / improvement of the optimal system or component so as to minimize matters including the number of BOGs, the high BOR and the occurrence of exergy destruction due to available energy through the tank wall is wasted into energy [16]. The purpose of this research is to study the exergy accompanying heat transfer characteristics through the tank wall of the three ISO-tank tank options on plate material parameters and insulation using physical model in COMSOL Multiphysics 5.1 Academic Server License software [17]. Then determine the value of BOR and the number of BOG on the three ISO-tank tank options and provide the exterior and BOR analysis results of the three tank options along with their relationship, the tank laying analysis and provide recommended tank selection suggestions later in the form of a quality scale matrix, which will then serve as a basis for assessing the feasibility of a dual-fuel on ships using ISO-tank as an LNG fuel storage. The analysis consists of the rate of exergy transfer and destruction through tank wall due to heat transfer, boil-off rate and boil-off gas from stored LNG.

\section{Experimental Details}

\subsection{Review on Economic Feasibility Study}

The economic context cannot be excluded from the company's business plan, so the conversion impact is economically desirable to discuss, primarily to compare the results of the existing feasibility studies with academic studies, especially in this study which examines exergy performance and BOR BOG values from LNG storage tanks. Tables 1 and 2 form the basis for economic calculations that have been implemented by X Company, then furthermore, the results of the exergy performance assessment and BOR BOG will be used to verify whether the plan is really profitable or not. However, going back to the original purpose of X Company initiated this idea of converting a ship engine in order to use dual fuel for savings while lowering the impact of emissions on the environment, of course, these parameters are the least profitable. Required tank option is not the cheapest price, but with determining optimum price is expected to get optimum performance as well, especially the performance of the tank from the context of heat leaks that occur and the suitability of the amount of BOG produced throughout the tank with a substitution plan ratio of 40-60 for HSD and LNG [18].

Table 1: Routes and ship fuel consumption (MoT)

\begin{tabular}{lllllll}
\hline Route & Sail hour & & Berth hour & & Mileage \\
\hline Tg. Priok - Tg. Perak & 23 & hour & 24 & hour & 396 & Nmi \\
\hline Tg. Perak - Makassar & 26 & hour & 5 & hour & 458 & Nmi \\
\hline Makassar - Tg. Perak & 25 & hour & 6 & hour & 458 & $\mathrm{Nmi}$ \\
\hline Tg. Perak - Tg. Priok & 23 & hour & 3 & hour & 396 & $\mathrm{Nmi}$ \\
\hline Total 1 Voyage & 97 & hour & 38 & hour & 1708 & Nmi \\
\hline Consumption & 1968.68 & liter/h & 332.67 & liter/h & 17.61 & V \\
\hline Total 1 Voyage & 190961.96 & liter & 12641.46 & liter & 203603.42 & liter \\
\hline & & & & & 168990.8386 & $\mathrm{~kg}$
\end{tabular}

Table 2: Price matrix, density and LHV of fuel (reprocessed) (MoT)

\begin{tabular}{|c|c|c|c|c|c|}
\hline HSD & Value & Unit & LNG & Value & Unit \\
\hline \multirow{4}{*}{ Density, $\rho$} & & 1 & \multirow{4}{*}{$\rho$} & 450 & $\mathrm{~kg} / \mathrm{m}^{3}$ \\
\hline & 850 & $\mathrm{Kg} /$ & & 0.45 & $\mathrm{~kg} / \mathrm{L}$ \\
\hline & \multirow{2}{*}{0.83} & \multirow{2}{*}{$\mathrm{kg} / \mathrm{L}$} & & 24.02 & MMBtu $/ \mathrm{m}^{3}$ \\
\hline & & & & 18.73438801 & $\mathrm{~kg} / \mathrm{MMBtu}$ \\
\hline \multirow{2}{*}{$\begin{array}{l}\text { Price (Pertamina IFM } \\
\text { per } 30 \text { April 2018) }\end{array}$} & Rp10,700.00 & per liter & \multirow{2}{*}{$\begin{array}{l}\text { Price (PGN per } \\
30 \text { April 2018) }\end{array}$} & $\$ 9.95$ & per MMBtu \\
\hline & Rp12,891.57 & per kg & & Rp137,817.45 & per MMBtu \\
\hline \multirow{2}{*}{ LHV } & 10500 & $\mathrm{kcal} / \mathrm{kg}$ & \multirow{2}{*}{ LHV } & 12000 & $\mathrm{kcal} / \mathrm{kg}$ \\
\hline & 43932 & $\mathrm{~kJ} / \mathrm{kg}$ & & 50208 & $\mathrm{~kJ} / \mathrm{kg}$ \\
\hline
\end{tabular}




\subsection{Governing Equations of Simulation}

The rate of displacement and destruction of the physical exergy in a steady state can be calculated based on energy transfer due to heat transfer alone, due to the absence of energy converted into work, such that $\mathrm{Q}_{\text {in }}=\mathrm{Q}_{\text {out }}$. The transfer of exergy along with heat (exergy transfer accompanying heat transfer) on the inner surface can be evaluated by equation 1 as follows:

$$
\text { Exq, } 1=\left[1-\frac{T 0}{T 1}\right] Q / A
$$

Then for the value of exergy displacement along with the transfer of heat on the outer surface can be evaluated by equation 2 as follows:

$$
\text { Exq, } 2=\left[1-\frac{T 0}{T 2}\right] Q / A
$$

Furthermore, the value of exergy destruction can be evaluated from the difference between equation 1 (inner surface exergy displacement) and 2 (external exergy displacement) written into:

$$
E x, d=\frac{E x q, 1}{A}-\frac{E x q, 2}{A}
$$

Exergy efficiency can be evaluated by using equations 1 to 3 , where the exergetic efficiency is expressed by

$$
\eta E x=\frac{E x, o u t}{E x, \text { in }}
$$

A simple approach to modeling heat leak calculations on a cylindrical tank with a torispheroidal dome cap can be performed with an ordinary cylindrical shell model with the determination of the shell layers and insulation as shown in Fig. 1, due to similar cross-section shape and the difference in both not much different as described in the study by Rossios [19]. This modeling utilizes the combined equation between the heat conduction through the composite wall and the heat conduction through the cylindrical wall with the ambient air ambient and the fluid temperature within the specified cylinder [20].

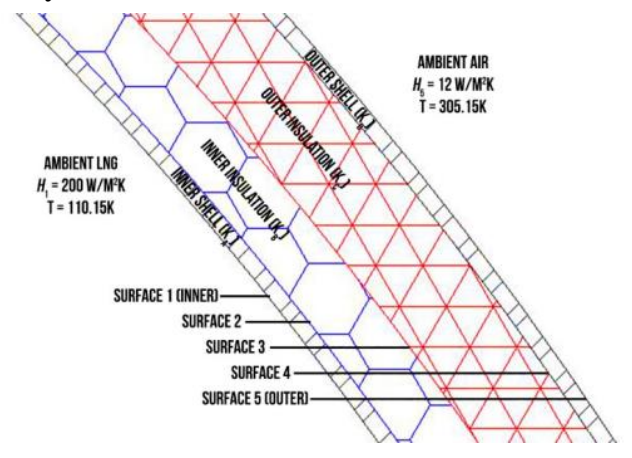

Fig. 1: Temperature distribution on cylindrical composite walls.
The calculation of the one-dimensional steady state heat transfer rate for layered cylinders taking into account the ambient fluid inside and around this cylinder can be described as follows:

$$
q_{r}=\frac{T_{\infty, 1}-T_{\infty, 4}}{\frac{1}{2 \pi r_{1} L h_{1}}+\frac{\ln \left(r_{2} / r_{1}\right)}{2 \pi k_{\mathrm{A}} L}+\frac{\ln \left(r_{3} / r_{2}\right)}{2 \pi k_{\mathrm{B}} L}+\frac{\ln \left(r_{4} / r_{3}\right)}{2 \pi k_{\mathrm{C}} L}+\frac{1}{2 \pi r_{4} L h_{4}}}
$$

which can be written also by using the overall heat transfer coefficient $U$ as follows:

$$
q_{r}=\frac{T_{\infty, 1}-T_{\infty, 4}}{R_{\text {tot }}}=U A\left(T_{\infty, 1}-T_{\infty, 4}\right)
$$

where $R_{\text {tot }}$ is the total thermal resistance value. If $U$ is defined it corresponds to the inner width, $\mathrm{A}_{1}=2 \mathrm{r}_{1} \mathrm{~L}$, equations 5 and 6 can be synchronized to get:

$$
U_{1}=\frac{1}{\frac{1}{h_{1}}+\frac{r_{1}}{k_{\mathrm{A}}} \ln \frac{r_{2}}{r_{1}}+\frac{r_{1}}{k_{\mathrm{B}}} \ln \frac{r_{3}}{r_{2}}+\frac{r_{1}}{k_{\mathrm{C}}} \ln \frac{r_{4}}{r_{3}}+\frac{r_{1}}{r_{4}} \frac{1}{h_{4}}}
$$

This definition can be changed, and $U$ values can also be found from $\mathrm{A}_{4}$ or other middle area. Note that:

$$
U_{1} A_{1}=U_{2} A_{2}=U_{3} A_{3}=U_{4} A_{4}=\left(\Sigma R_{t}\right)^{-1}
$$

and the specific form of $U_{2}, U_{3}$ dan $U_{4}$ can be derived from equations 7 and 8 . The rate of heat transfer through each layer has a constant value as thick as that wall, as stated in the equation:

$$
\dot{Q}=\frac{\Delta T(i-j)}{R i j}(W)
$$

with $\Delta \mathrm{T}_{\mathrm{i}-\mathrm{j}}$ is the difference between the temperatures on surface $i$ and surface $j$ on the material layer $i j$, and the thermal value of the conductive thermal resistance $R_{\text {cond }}$ obtained from the thermal conductivity value $k$. For cylindrical composite walls, the equations used are as follows:

$$
\text { Rcond, cyl }=\frac{\ln \left(\frac{r j}{r i}\right)}{2 \pi L k} \quad(K / W)
$$

with the natural logarithm value of the ratio of $r$ (radius) from the center of the cylinder to the outer surface $i$ to the inner surface $\mathrm{j}$, provided that $\mathrm{r}_{\mathrm{i}}>\mathrm{r}_{\mathrm{j}}, L$ is the length of the cylinder and $k$ specific for the material being passed. If heat transfer occurs between ambient air contacting the first surface of a composite wall, or from the final surface of a wall, the convective thermal resistance $R_{\text {conv }}$ can be calculated by the following equation: 
Table 3: ISO-tank options comparation matrix

\begin{tabular}{|c|c|c|c|c|c|c|c|c|}
\hline \multirow[b]{2}{*}{ Option } & \multirow[b]{2}{*}{ Supplier } & \multirow[b]{2}{*}{ ISO Size } & \multirow[b]{2}{*}{$\begin{array}{c}\text { Inner } \\
\text { Diameter }\end{array}$} & \multirow[b]{2}{*}{$\begin{array}{c}\text { Outer } \\
\text { Diameter }\end{array}$} & \multicolumn{4}{|c|}{ Shell } \\
\hline & & & & & Material & $\begin{array}{c}\text { Inner } \\
\text { thickness }\end{array}$ & $\begin{array}{c}\text { Outer } \\
\text { thickness }\end{array}$ & $\begin{array}{c}\text { Thermal } \\
\text { conductivity } \\
@ 300 \mathrm{~K}\end{array}$ \\
\hline $\mathrm{A}$ & Trencor & \multirow{3}{*}{$20 \mathrm{ft}$} & \multirow{3}{*}{$2200 \mathrm{~mm}$} & $2320 \mathrm{~mm}$ & AISI 304 & $5 \mathrm{~mm}$ & $5 \mathrm{~mm}$ & $14.9 \mathrm{~W} / \mathrm{m} . \mathrm{K}$ \\
\hline B & Odyssey & & & $2424 \mathrm{~mm}$ & AISI 316L & $6 \mathrm{~mm}$ & $6 \mathrm{~mm}$ & $13.4 \mathrm{~W} / \mathrm{m} . \mathrm{K}$ \\
\hline $\mathrm{C}$ & Taizhou & & & $2322 \mathrm{~mm}$ & Titanium & $8 \mathrm{~mm}$ & $8 \mathrm{~mm}$ & $21.9 \mathrm{~W} / \mathrm{m} . \mathrm{K}$ \\
\hline \multirow{3}{*}{ Option } & \multirow{3}{*}{ Supplier } & \multirow{3}{*}{$\begin{array}{c}\text { Net } \\
\text { capacity }\end{array}$} & \multicolumn{6}{|c|}{ Insulation } \\
\hline & & & \multicolumn{3}{|c|}{ First layer } & \multicolumn{3}{|c|}{ Second layer } \\
\hline & & & Type & Thickness & $\begin{array}{c}\text { Thermal } \\
\text { conductivity }\end{array}$ & Type & Thickness & $\begin{array}{c}\text { Thermal } \\
\text { conductivity }\end{array}$ \\
\hline A & Trencor & & Polyurethane & $20 \mathrm{~mm}$ & $26 \mathrm{~mW} / \mathrm{m} \cdot \mathrm{K}$ & Rockwool & $30 \mathrm{~mm}$ & $35 \mathrm{~mW} / \mathrm{m} . \mathrm{K}$ \\
\hline B & Odyssey & 21000 & Glasswool & $50 \mathrm{~mm}$ & $35 \mathrm{~mW} / \mathrm{m} . \mathrm{K}$ & Rockwool & $50 \mathrm{~mm}$ & $35 \mathrm{~mW} / \mathrm{m} . \mathrm{K}$ \\
\hline $\mathrm{C}$ & Taizhou & & Polystyrene & $20 \mathrm{~mm}$ & $33 \mathrm{~mW} / \mathrm{m} . \mathrm{K}$ & GFRP & $25 \mathrm{~mm}$ & $36 \mathrm{~mW} / \mathrm{m} . \mathrm{K}$ \\
\hline
\end{tabular}

$$
\text { Rconv, } \operatorname{cyl}=\frac{1}{2 \pi r L h}(K / W)
$$

The thermal resistance works on a principle more or less the same as the electrical resistance, in series as in the cylindrical composite wall of Fig. 1 before, the $R$ value is

cumulative, with $R_{\text {total }}$ being the divisor of equation 5 above. Knowing the value of thermal resistance for each layer (incremental) and subtotal between layers (cumulative) will be useful to calculate the temperature on each layer surface numerically if the known temperature value is only external and internal ambient temperature [19]. Boil-off rate (BOR) or gas evaporation rate and percent boiloff gas (BOG) per day in an LNG tank modeling can be calculated by the following equation [21]:

$$
B O R\left(\frac{k g}{s}\right)=\frac{Q(W)}{\Delta H\left(\frac{j}{k g}\right)}
$$

with $\dot{Q}$ being the heat value of the system (heat leak) and $\Delta \mathrm{H}$ representing the latent heat of vaporization, i.e. $5.1 \times 10^{5}$ $\mathrm{J} / \mathrm{kg}$. Then the $\% \mathrm{BOG}$ value is calculated by the equation

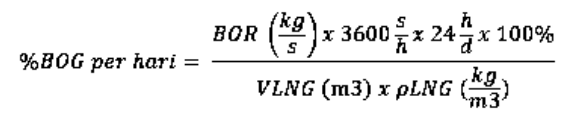

\subsection{Geometrical Dimensions}

The work of this paper will require some data before then the data can be processed and analyzed, with the main data provided by Ministry of Transportation and supporting data will be completed based on literature reference. The vessel to be analyzed is an Inter-island Ship Vessel owned by Ministry of Transportation, which serves the Tanjung Priok - Makassar route, a total distance of 1708 nautical miles and the total day of the screen and the day of the day is 5,625 days, the average speed is 17.6 knots. The study was a study of shell material variation and ISO-tank insulation on physical exergy characteristics and Boil-Off Rate LNG load value. There are 3 variations of tank options provided by $\mathrm{X}$ Company, with the specifications shown in Table 3.

Ship KM. C is planned to use a combination of LNG and HSD fuels with a ratio of $60-40, h=200 \mathrm{~W} / \mathrm{m}^{2} \mathrm{~K}$ with fuel specifications based on General Services Laboratory references [22] as follows:

$$
\begin{array}{ll}
\text { Origin } & : \text { Indonesia - Arun } \\
\text { Price rate } & : \text { US\$ 9.95 per MMBtu equivalent } \\
& \text { Rp137.817,45 per 30 April 2018 } \\
\text { LHV } & : 50208 \mathrm{~kJ} / \mathrm{kg} \\
\text { Density } & : 450 \mathrm{~kg} / \mathrm{m}^{3} \text { equivalent } 24.02 \mathrm{MMBtu} / \mathrm{m}^{3}
\end{array}
$$

Referring to Rossios, the tank will be modeled in the form of shell layers and cylinder insulation to facilitate calculations because of the same cross-sectional shape as the tank shape (i.e. the cylinder with the dome of the torispherical dome at both ends), and the difference in volume not much different. Modeling is done manually using formulas from literature references and journals shown in Fig. 2, later to be compared with modeling using COMSOL Multiphysics 5.1 software. (a)

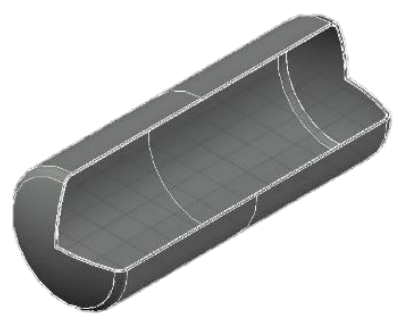

(b)

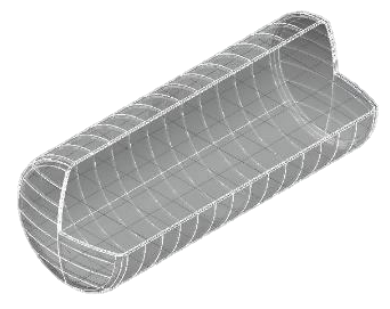

Fig. 2. 3-dimensional solid model (a) and mesh model (b) of ISO-tank. 


\subsection{Modeling and Simulation}

In this analysis there will be exchanged rate of heat exergy $E x_{q}$ rate, exergy destruction rate $E x_{d}$ and $\eta E x$ exergetic efficiency. Similar to the modeling stage, the exergy analysis will be performed with manual calculations based on the formulas of literature references and journals, then will be compared with hot flux analysis using COMSOL Multiphysics 5.1 software with the steps briefly shown in Fig. 3 and 4. Modeling for each tank is done by selecting the Heat Transfer in Solids module with the stationary study type, then constructing a model of cylindrical shell layers with caps for each material in accordance with the specifications.

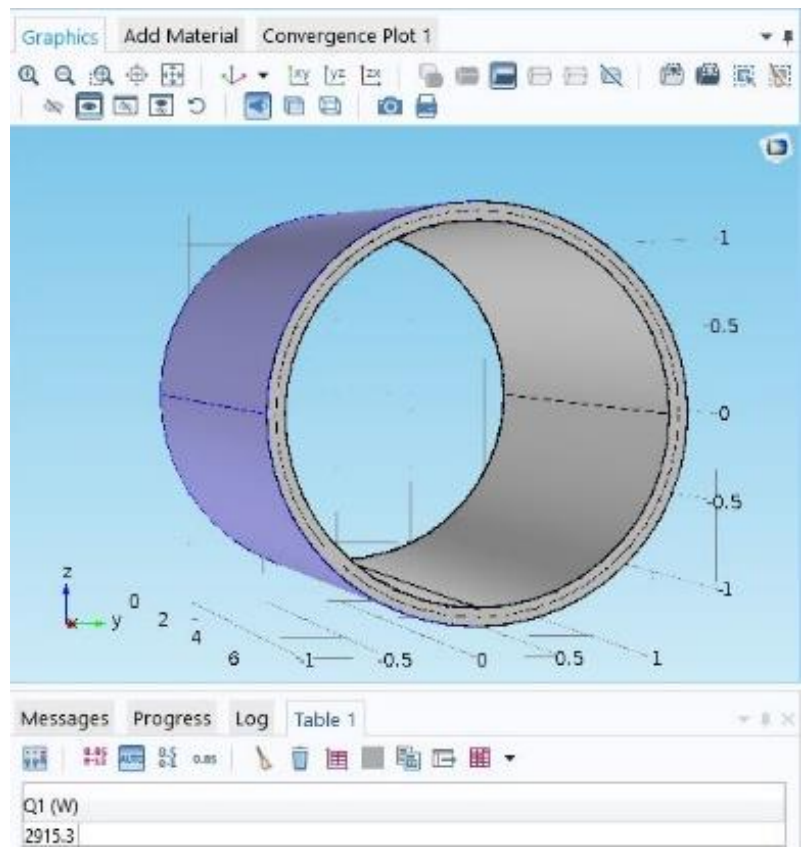

Fig. 3. Construction of cylinder layer on COMSOL 5.1.

Then the heat flux value from the outer wall and the inner wall of the tank is calculated using the surface average, and the temperature distribution in each layer is calculated using the line average. From this model we will also obtain a heat map due to heat transfer from outside the tank (ambient air) into the tank (LNG assumed ambient) through each layer of the tank wall. Data obtained from COMSOL can then be exported and then processed by the equations of the literature to obtain exergy displacement values, exergy efficiency and BOR characteristics as well as BOG for each type of tank modeled.

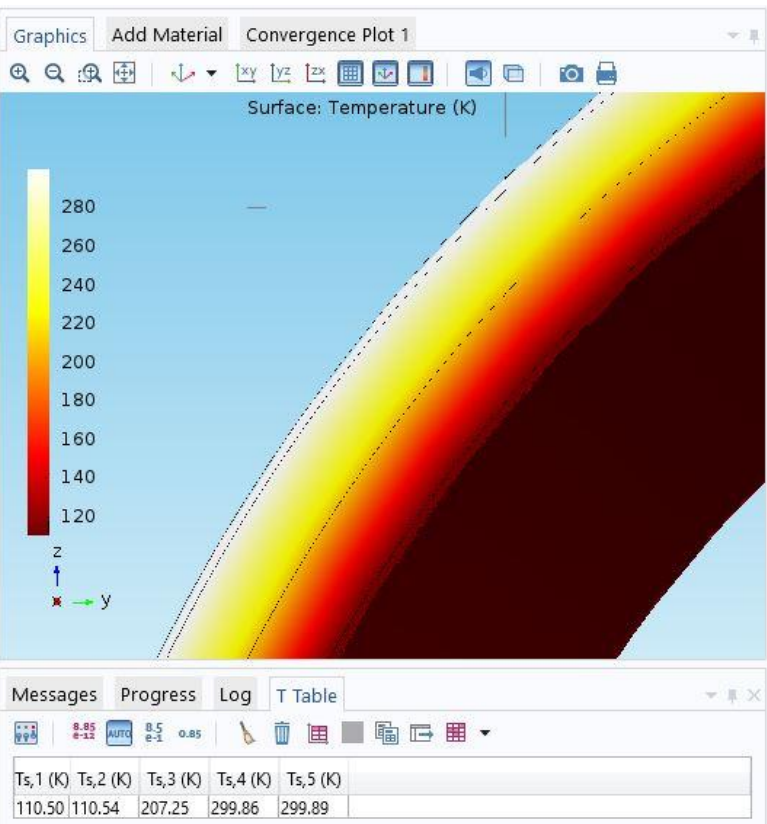

Fig. 4: Calculation of temperature distribution and heat leak through the wall on COMSOL 5.1.

\subsection{Validation Results}

As far as the authors of this paper concerned, there are no recent papers with more or less similar topics to refer to, and with that being said the validation is conducted between numerical and software calculations on $\mathrm{T}$ and $\dot{Q}$ values (which are shown in Table 4 on the following section) to determine the relative error of both parameters. The error percentage of each parameter for each option are as follows:

\section{Option A (Trencor)}

- $\dot{Q}$ value $=\mathbf{0 . 1 8 3 \%}$

- Average Ts, ${ }_{5}$ to $\mathrm{Ts},{ }_{1}$ value $\mathbf{= 0 . 1 1 5 \%}$

Option B (Odyssey)

- $\dot{Q}$ value $=\mathbf{0 . 0 4 3 \%}$

- $\quad$ Average $\mathrm{Ts}, 5$ to $\mathrm{Ts}, 1$ value $=\mathbf{0 . 0 1 1 \%}$

Option C (Taizhou)

- $\dot{Q}$ value $=0.063 \%$

- $\quad$ Average $\mathrm{Ts}, 5$ to $\mathrm{Ts}, 1$ value $\mathbf{= 0 . 0 3 4 \%}$

The relatively small error percentage as a result of simulation's validation implied that both of the numerical and software calculations are based on the same equations with small margin of error. 


\section{Results \& Discussions}

To find the value of temperature on each surface numerically, firstly used equations 10 and 11 to find the value of thermal resistance of each layer on the tank wall with the arrangement in Fig. 1. Furthermore, manual calculation of $\dot{\boldsymbol{Q}}$ based on the formula derived from the literature, especially equations 6 to 8 , and then comparable with the modeling results using COMSOL Multiphysics 5.1 software. From the results of modeling using the software will get the outer and inner surface $\dot{\boldsymbol{Q}}$ value, along with surface temperatures on each surface of the tank wall layers. Using the thermal resistance value, the temperature at each layer surface is also numerically searched using equation 9 . The data obtained will be used to calculate the displacement and destruction of exergy and its efficiency, described in Table 4 for each tank.

Table 4: Option A, B and C's T and $\dot{\boldsymbol{Q}}$ values

\begin{tabular}{|c|c|c|}
\hline Option A (Trencor) & Numerical & Software \\
\hline$\dot{Q}$ & $4885.42 \mathrm{~W}$ & $4894.39 \mathrm{~W}$ \\
\hline $\mathrm{T}_{\infty, 5}$ (ambient air) & $305.15 \mathrm{~K}$ & $305.15 \mathrm{~K}$ \\
\hline $\mathrm{T}_{\mathrm{s} 5}($ surface 5$)$ & $295.93 \mathrm{~K}$ & $295.85 \mathrm{~K}$ \\
\hline $\mathrm{T}_{\mathrm{s} 4}($ surface 4$)$ & $295.89 \mathrm{~K}$ & $295.81 \mathrm{~K}$ \\
\hline $\mathrm{T}_{\mathrm{s} 3}($ surface 3$)$ & $199.38 \mathrm{~K}$ & $200.31 \mathrm{~K}$ \\
\hline $\mathrm{T}_{\mathrm{s} 2}($ surface 2$)$ & $110.83 \mathrm{~K}$ & $110.81 \mathrm{~K}$ \\
\hline $\mathrm{T}_{\mathrm{s} 1}($ surface 1$)$ & $110.77 \mathrm{~K}$ & $110.74 \mathrm{~K}$ \\
\hline $\mathrm{T}_{\infty, 1}($ ambient LNG) & $110.15 \mathrm{~K}$ & $110.15 \mathrm{~K}$ \\
\hline Option B (Odyssey) & Numerical & Software \\
\hline$\dot{Q}$ & $2913.32 \mathrm{~W}$ & $2914.56 \mathrm{~W}$ \\
\hline $\mathrm{T}_{\infty, 5}$ (ambient air) & $305.15 \mathrm{~K}$ & $305.15 \mathrm{~K}$ \\
\hline $\mathrm{T}_{\mathrm{s} 5}($ surface 5$)$ & $299.89 \mathrm{~K}$ & $299.89 \mathrm{~K}$ \\
\hline $\mathrm{T}_{\mathrm{s} 4}($ surface 4$)$ & $299.86 \mathrm{~K}$ & $299.86 \mathrm{~K}$ \\
\hline $\mathrm{T}_{\mathrm{s} 3}$ (surface 3 ) & $207.26 \mathrm{~K}$ & $207.25 \mathrm{~K}$ \\
\hline $\mathrm{T}_{\mathrm{s} 2}($ surface 2$)$ & $110.57 \mathrm{~K}$ & $110.54 \mathrm{~K}$ \\
\hline $\mathrm{T}_{\mathrm{s} 1}($ surface 1$)$ & $110.52 \mathrm{~K}$ & $110.50 \mathrm{~K}$ \\
\hline $\mathrm{T}_{\infty, 1}$ (ambient LNG) & $110.15 \mathrm{~K}$ & $110.15 \mathrm{~K}$ \\
\hline Option C (Taizhou) & Numerical & Software \\
\hline$\dot{Q}$ & $6042.29 \mathrm{~W}$ & $6046.09 \mathrm{~W}$ \\
\hline $\mathrm{T}_{\infty, 5}$ (ambient air) & $305.15 \mathrm{~K}$ & $305.15 \mathrm{~K}$ \\
\hline $\mathrm{T}_{\mathrm{s} 5}$ (surface 5 ) & $293.76 \mathrm{~K}$ & $293.75 \mathrm{~K}$ \\
\hline $\mathrm{T}_{\mathrm{s} 4}$ (surface 4) & $293.71 K$ & $293.70 \mathrm{~K}$ \\
\hline $\mathrm{T}_{\mathrm{s} 3}$ (surface 3 ) & $197.04 \mathrm{~K}$ & $197.00 \mathrm{~K}$ \\
\hline $\mathrm{T}_{\mathrm{s} 2}($ surface 2$)$ & $110.99 \mathrm{~K}$ & $110.91 \mathrm{~K}$ \\
\hline $\mathrm{T}_{\mathrm{s} 1}($ surface 1$)$ & $110.95 \mathrm{~K}$ & $110.87 \mathrm{~K}$ \\
\hline $\mathrm{T}_{\infty, 1}$ (ambient LNG) & $110.15 \mathrm{~K}$ & $110.15 \mathrm{~K}$ \\
\hline
\end{tabular}

The characteristics of the temperature distribution line in Fig. 5 indicate conformity with the literature, where the

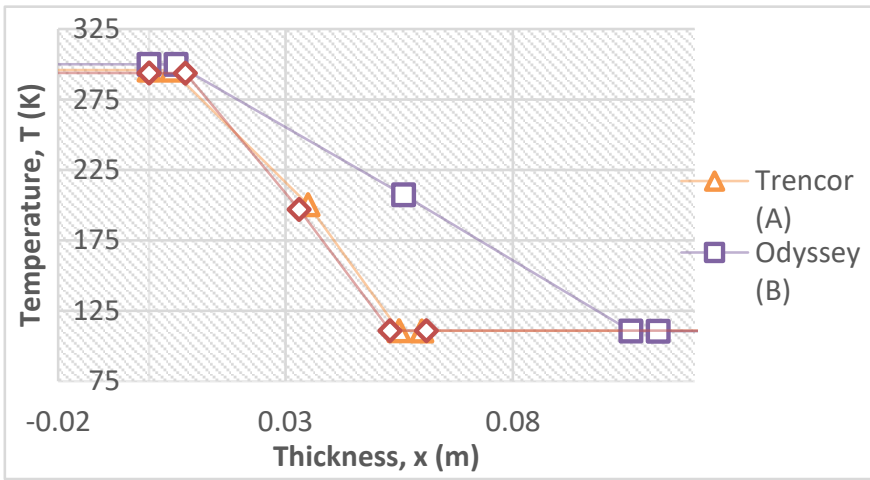

temperature appears to drop drastically as it passes through the insulation. This is a temperature drop (temperature drop) calculated using equation 9 with the value $\dot{\boldsymbol{Q}}$ which has been obtained previously (which is the same value on each surface) and the thermal resistance value of each layer to be determined its surface temperature values.

Fig. 5: Temperature distribution diagram on the tank wall.

Furthermore, the $T$ and $\dot{Q}$ values obtained above will be processed using equations 1 to 4 to obtain exergy transfer rate values in conjunction with the heat transfer $\left(E x_{q}\right)$, destruction and exergetic efficiency of heat transfer from the three designed tank models [23]. The value of $\dot{Q}$ to be used from each tank is the largest, i.e. $\dot{Q}_{\text {soffware }}$, outlined in Table 5.

Table 5: Transfer rate, destruction and exergy efficiency for each ISO-tank option.

\begin{tabular}{lcc}
\hline \multicolumn{3}{c}{ Option A (Trencor) } \\
\hline$E x_{q, \text { in }}$ & 8592.64 & $\mathrm{~W}$ \\
$E x_{q, \text { out }}$ & 8438.79 & $\mathrm{~W}$ \\
$E x_{d}$ & 153.85 & $\mathrm{~W}$ \\
$\eta E x$ & $98.21 \%$ \\
\hline \multicolumn{3}{c}{ Option B (Odyssey) } \\
\hline$E x_{q, \text { in }}$ & 5134.27 & $\mathrm{~W}$ \\
$E x_{q, \text { out }}$ & 5083.12 & $\mathrm{~W}$ \\
$E x_{d}$ & 51.15 & $\mathrm{~W}$ \\
$\eta E x$ & $99.00 \%$ & \\
\hline \multicolumn{3}{c}{ Option C (Taizhou) } \\
\hline$E x_{q, \text { in }}$ & 10594.42 & $\mathrm{~W}$ \\
$E x_{q, \text { out }}$ & 10359.81 & $\mathrm{~W}$ \\
$E x_{d}$ & 234.61 & $\mathrm{~W}$ \\
$\eta E x$ & $97.79 \%$ &
\end{tabular}


Table 6: The value of BOR, BOG and the additional percentage required for each tank option.

\begin{tabular}{lll}
\hline \multicolumn{3}{c}{ Option A (TRENCOR) } \\
\hline Net volume & 21 & $\mathrm{~m}^{3}$ \\
$\dot{Q}$ & 4894.393 & $\mathrm{~W}$ \\
$\Delta H$, vapor latent heat (IGU) & 510000 & $\mathrm{~J} / \mathrm{kg}$ \\
pLNG & 450 & $\mathrm{~kg} / \mathrm{m}^{3}$ \\
BOR per tank unit & 0.00960 & $\mathrm{~kg} / \mathrm{s}$ \\
Required addition & $49.40 \%$ & $\left(\dot{m}_{\mathrm{LNG}, 60}\right)$ \\
BOG & $8.77 \%$ & per day \\
\hline \multicolumn{3}{c}{ Option B (ODYSSEY) } \\
\hline Net volume & 21 \\
$\dot{Q}$ & 2914.565 & $\mathrm{~m}$ \\
$\Delta H$, vapor latent heat (IGU) & 510000 & $\mathrm{~J} / \mathrm{kg}$ \\
pLNG & 450 & $\mathrm{~kg} / \mathrm{m}^{3}$ \\
BOR per tank unit & 0.00572 & $\mathrm{~kg} / \mathrm{s}$ \\
Required addition & $69.87 \%$ & $\left(\dot{m}_{\mathrm{LNG}, 60}\right)$ \\
BOG & $5.22 \%$ & $\mathrm{per} \mathrm{day}$ \\
\hline \multicolumn{3}{c}{ Option C (TAIZHOU) } \\
\hline Net volume & 21 & $\mathrm{~m}$ \\
$\dot{Q}$ & 6046.092 & $\mathrm{~W}$ \\
$\Delta H$, vapor latent heat (IGU) & 510000 & $\mathrm{~J} / \mathrm{kg}$ \\
pLNG & 450 & $\mathrm{~kg} / \mathrm{m}^{3}$ \\
BOR per tank unit & 0.01186 & $\mathrm{~kg} / \mathrm{s}$ \\
Required addition & $37.49 \%$ & $\left(\dot{m}_{\mathrm{LNG}, 60}\right)$ \\
BOG & $10.84 \%$ & $\mathrm{per} \mathrm{day}$
\end{tabular}

In Table 6 we calculated the specific BOR and BOG values for each tank using equations 12 and 13 , and the BOR value in $\mathrm{kg} / \mathrm{s}$ obtained from each tank multiplied by the number of tanks used in accordance with the feasibility study data of Ministry of Transportation of the Republic of Indonesia, i.e. 11 ISO-tank tanks, to determine the natural BOR produced by the environmental conditions and how big the difference with the BOR required to achieve substitution of $60 \%(0.209 \mathrm{~kg} / \mathrm{s})$.

The additional value required is intended as an addition to the flow rate of the converted gas phase LNG mass to meet the fuel substitution requirements of the option tanks $\mathrm{A}, \mathrm{B}$ and $\mathrm{C}$ will require forced vaporizer to evaporate additional gas $\left(\dot{m}_{\text {vaporizer }}\right)$ with a certain percentage against $\dot{m}_{\mathrm{LNG}, 60}$ at a maximum of $0.209 \mathrm{~kg} / \mathrm{s}$, i.e. $49.40 \%(0.103$ $\mathrm{kg}), 69.87 \%(0.146 \mathrm{~kg})$ and $37.49 \%(0.078 \mathrm{~kg})$ per second respectively, for a total of 1 voids, an additional LNG vapor total of $50089.75 \mathrm{~kg}, 70843.01 \mathrm{~kg}$ and $38017.24 \mathrm{~kg}$ of each tank option to meet the mode of fuel HSD-LNG ratio of 4060 , and the need for additional heat for evaporation can be calculated by multiplying the value $\dot{m}_{\text {vaporizer }}$ with the latent heat value $\Delta H$ as shown in Table 7.

Table 7: Additional flow rate of LNG vapor and vaporizer heat required.

\begin{tabular}{llll}
\hline Tank option & $\dot{\boldsymbol{m}}_{\text {vaporizer }}$ & Total 1 voyage & $\dot{\boldsymbol{Q}}_{\text {vaporizer }}$ \\
\hline A. Trencor & $0.10307 \mathrm{~kg} / \mathrm{s}$ & $50089.7 \mathrm{~kg}$ & $52.56 \mathrm{~kW}$ \\
B. Odyssey & $0.14577 \mathrm{~kg} / \mathrm{s}$ & $70843 \mathrm{~kg}$ & $74.34 \mathrm{~kW}$ \\
C. Taizhou & $0.07822 \mathrm{~kg} / \mathrm{s}$ & $38017.2 \mathrm{~kg}$ & $39.90 \mathrm{~kW}$
\end{tabular}

The data obtained for each tank option from this analysis and also the previous analysis can be compiled into a matrix of comparison of each parameter and its value for subsequent interpretation of the relationship between one parameter to another as described in Table 8.

Table 8: Matrix comparison of tank analysis parameters.

\begin{tabular}{lllllll}
\hline Tank option & $\boldsymbol{R}_{\text {tot }}$ & $\dot{\boldsymbol{Q}}$ & $\boldsymbol{E} \boldsymbol{x}_{\mathbf{d}}$ & $\boldsymbol{\eta} \boldsymbol{E} \boldsymbol{x}_{\mathbf{q}}$ & $\begin{array}{l}\text { \% BOG } \\
\text { per day }\end{array}$ & $\dot{\boldsymbol{Q}}_{\text {vaporizer }}$ \\
& $(\mathbf{K} / \mathbf{W})$ & $(\mathbf{W})$ & $(\mathbf{W})$ & $(\boldsymbol{\%})$ & & $(\mathbf{k W})$ \\
\hline A. Trencor & 0.0399065 & 4894.39 & 153.8460 & $98.21 \%$ & $8.77 \%$ & 52.56 \\
B. Odyssey & 0.0669249 & 2914.56 & 51.1532 & $99.00 \%$ & $5.22 \%$ & 74.34 \\
C. Taizhou & 0.0322595 & 6046.09 & 234.6119 & $97.79 \%$ & $10.84 \%$ & 39.90
\end{tabular}

From Table 8, there is a tendency that the smaller total thermal resistance $R_{\text {tot }}$ will have an impact on the increase of heat leak $\dot{Q}$, the destruction rate of heat exergy through the tank wall $E x_{\mathrm{d}}$, the percentage of boil-off gas formed per day and the additional heat required from the forced vaporizer to produce an additional steam flow rate of $\mathrm{LNG}$ that can meet the fuel substitution requirement with LNG by $60 \%$, but the exergetic efficiency of $\eta E x_{q}$ will decrease further. This explains the effect of shell material variation and the insulation used on the tank wall, that if the quality of the material in this context is measured by the thermal conductivity value $k$, then the material with the least thermal conductivity value $\mathrm{k}$ gives the hot dampening quality of the best tank with the greatest exergetic efficiency which means the exergy being destroyed or wasted into the environment is getting smaller [24].

The tank quality scale will be based on data and analysis of the results obtained, to facilitate the presentation of data and processes to further consider which tanks will be selected. The quality scale is based on measurable values in Table 9, i.e. the exergetic efficiency parameters measured in the power loss due to destruction of exergy in $\mathrm{kW}$ and power due to the need for additional heat by the forced vaporizer to increase the gas vapor mass flow rate in $\mathrm{kW}$, with exergy cost of US \$0.08/ $\mathrm{kWh}$ and the foreign exchange rate used is Rp13,851, - per US dollar as of April 
30,2018 and the total of 1 voyage trip has an interval of 135 hours [25].

Exergy cost is the cost of loss due to the rate of destruction of exergy occurring during LNG stored in the tank, obtained from the amount of exergy destroyed in each tank, multiplied by the total number of tanks used, the total shipping hours and the exergy cost per $\mathrm{kWh}$, due to destruction exergy occurs simultaneously for each tank transported on board. While the cost of $\dot{Q}_{\text {vaporizer }}$ is already the total power requirement for the additional vaporization heat of the total tank amount used to meet the LNG substitution of $\dot{m}_{\mathrm{LNG}, 60}$ by $0.209 \mathrm{~kg} / \mathrm{s}$, multiplied by the total shipping hours and the cost per $\mathrm{kWh}$.

Table 9: Matrix of tank quality scale in additional cost per voyage.

\begin{tabular}{lll|rrrr}
\hline Option & \multicolumn{5}{c}{ Exergy cost for 11 tanks } \\
& $\mathrm{kW}$ & $\mathrm{kWh}$ & Cost & & \\
\hline Trencor & 1.69 & 228.46 & $\$$ & 18.28 & $\mathrm{Rp}$ & $253,153.39$ \\
Odyssey & 0.56 & 75.96 & $\$$ & 6.08 & $\mathrm{Rp}$ & $84,172.56$ \\
Taizhou & 2.58 & 348.40 & $\$$ & 27.87 & $\mathrm{Rp}$ & $386,053.67$ \\
\hline Option & \multicolumn{5}{c}{ Cost of $\dot{\boldsymbol{Q}}_{\text {vaporizer }}$} \\
& $\mathrm{kW}$ & $\mathrm{kWh}$ & $\mathrm{Cost}$ & & \\
\hline Trencor & 52.56 & 7096.05 & $\$ 567.68$ & $\mathrm{Rp}$ & $7,862,988.45$ \\
Odyssey & 74.34 & 10036.09 & $\$ 802.89$ & $\mathrm{Rp} 11,120,793.81$ \\
Taizhou & 39.89 & 5385.78 & $\$ 430.86$ & $\mathrm{Rp}$ & $5,967,869.81$
\end{tabular}

\section{Conclusions \& Recommendations}

The analysis of this study shows that the physical exergy characteristics of the LNG storage tank (in this context is the T75 ISO-tank type) and the gas evaporation rate or BOR can be parameters to determine the thermodynamic performance of the tank, determined by empirical equations of literature and modeling physical use of software has been comparable with feasibility study undertaken by Ministry of Transportation of the Republic of Indonesia to verify the results of the study whether the options given in the realization of this plan are really feasible to work on and can generate profits. The conclusions obtained based on modeling and analysis of this research are as follows:

- The smaller the value will affect greater value of heat leak through the tank wall and the greater the value of exergy that is removed and destroyed. Amount of exergy physically destroyed from exergy displacement together with heat transfer from each tank (a) Trencor, (b) Odyssey and (c) Taizhou is $153.8460 \mathrm{~W}, 51.1532 \mathrm{~W}$ and 234.6119 W.

- Exergetic efficiency is a characteristic that shows how efficiently a system is to keep exergy or energy available for use in order to remain usable (how much exergy is wasted due to differences in system temperature and environment). The smaller the value of $\boldsymbol{R}_{\text {tot }}$ the better the thermal insulation capability of a system such that the value of exergetic efficiency is greater. The exergetic efficiency values for each tank (a), (b), and (c) are $98.21 \%, 99.00 \%$ and $97.79 \%$.

Thus, it can be inferred feasible to apply and, theoretically, based on the quality scale that has been made, ISO-tank Option C (Taizhou) is the most feasible tank option to choose, due to its exergy loss the greatest loss compared to other tanks, this loss is covered with the minimum power requirement for the smallest forced vaporizer due to the total BOR value of 11 Taizhou tanks most closely related to demand $(0.13041 \mathrm{~kg} / \mathrm{s}$, only $37.49 \%$ less than $0.209 \mathrm{~kg} / \mathrm{s}$ ).

The authors' suggestion is to consider other ISO-tank options for LNG storage, with the following criteria:

- The combination of shell and insulation material used on the tank wall has a total thermal resistance value of $\mathrm{R}_{\text {tot }}$ not much different from 0.0201595 $\mathrm{K} / \mathrm{W}$, which can be calculated from the thermal conductivity value of each layer of material, thereby

- For each ISO-tank unit of $21 \mathrm{~m} 3$, the total heat leak produced is not much different from $9672.876 \mathrm{~W}$, causing

- Total BOR generated from the entire tank is not far from the requirement of gas fuel mass flow rate for dual fuel mode with a 40:60 HSD-LNG ratio of $0.209 \mathrm{~kg} / \mathrm{s}$ of LNG vapor, or equal to $0.01897 \mathrm{~kg} / \mathrm{s}$ BOR for each unit tank, in order to minimize the need to use forced vaporizer to meet the $\dot{\boldsymbol{m}}_{\mathrm{LNG}, 60}$ required. Is suggested to simulate the effect of emission from the dual fuel engine for further investigation [26].

\section{Acknowledgements}

Authors would like to express our grandest gratitude towards Ministry of Transportation of the Republic of Indonesia and X Company, Mr. Rahmat Budiman from Pertamina Gas and Mr. Lathif Prasetyo Wibisono from Patria Maritim Perkasa, also the Department of Mechanical Engineering University of Indonesia.

\section{References}

1) C. Migliore, C. Tubilleja, V. Vesovic, Weathering prediction model for stored liquefied natural gas (LNG), J Nat Gas Sci Eng, 26 (2015), pp. 570-580

2) J. Romero Gómez, M. Romero Gómez, J. Lopez Bernal, A. Baaliña Insua, Analysis and efficiency enhancement of a boil-off gas reliquefaction system with cascade cycle on board LNG carriers, Energy Convers Manag, 94 (2015), pp. 261-274 
3) K.D. Timmerhaus, R.P. Reed, Cryogenic engineering. International cryogenics monograph series, SpringerVerlag, New York (2007)

4) T. Gavory, P.E. de Seze, Sloshing in membrane LNG carriers and its consequences from a designer's perspective. Proceedings of 19th ISOPE, International Society of Offshore and Polar Engineers (ISOPE), Osaka, Japan (2009)

5) R.Z. Ríos-Mercado, C. Borraz-Sánchez, Optimization problems in natural gas transportation systems: a stateof-the-art review, Appl Energy, 147 (2015), pp. 536555

6) M. Miana, R. Legorburo, D. Díez, Y.H. Hwang, Calculation of boil-off rate of liquefied natural gas in Mark III tanks of ship carriers by numerical analysis, Appl Therm Eng, 93 (2016), pp. 279-296

7) Dincer, I., \& Rosen, M. A. (2015). Exergy Analysis of Heating, Refrigerating and Air Conditioning: Methods and Applications. https://doi.org/10.1016/C2013-006800-4

8) Moran, M. J., \& Shapiro, H. N. (2014). Fundamentals of Engineering Thermodynamics (8th ed.). https://doi.org/10.1016/0020-7403(63)90046-8

9) D. Yeo, B. Ahn, J. Kim, I. Kim, Propulsion Alternatives for Modern LNG Carriers. Proceedings of 15th international conference and exhibition on LNG, Gas Technology Institute (GTI), Barcelona, Spain (2007)

10) E. Ekanem Attah, R. Bucknal. An analysis of the energy efficiency of LNG ships powering options using the EEDI, Ocean Eng, 110 (2015), pp. 62-74

11) W.S. Wayne, M. Hodgson, The options and evaluation of propulsion systems for the next generation of LNG carriers. Proceedings of 23 rd world gas conference, International Gas Union (IGU), Amsterdam, Netherlands (2006)

12) I.A. Fernández, M.R. Gómez, J.R. Gómez, Á.B. Insua, Review of propulsion systems on LNG carriers, Renew Sustain Energy Rev, 67 (2017), pp. 1395-1411

13) Akamine, H., Mitsuhara M., et. al., Developments of Coal-Fired Power Plants: Microscopy Study of Fe-Ni Based Heat-Resistant Alloy for Efficiency Improvement, Evergreen, 2016-09 doi.org/10.5109/1800871

14) Y. Lee, T. Cho, J. Lee, O. Kwon, Trends and technologies in LNG carriers and offshore LNG facilities. Proceedings of offshore technology conference (OTC 2008), Offshore Technology Conference (OTC), Houston, USA (2008)
15) R. Gilmore, S. Hatzigrigoris, S. Mavrakis, A. Spertos, A. Vordonis, LNG carrier alternative propulsion systems. Proceedings of the Greek section of SNAME, Society of Naval Architects and Marine Engineers (SNAME), Athens (2005)

16) Romero Gómez, J., Romero Gómez, M., Lopez Bernal, J., \& Baaliña Insua, A. (2015). Analysis and efficiency enhancement of a boil-off gas reliquefication system with cascade cycle on board LNG carriers. Energy Conversion and Management, 94(x), 261-274. https://doi.org/10.1016/j.enconman.2015.01.074

17) Comsol Multiphysics® V. 5.1, www.comsol.com, COMSOL AB, Stockholm, Sweden.

18) DNV GL. (2016). LNG as ship fuel - DNV GL, (June). Retrieved from https://www.dnvgl.com/maritime/lng/index.html

19) Rossios, K., Sardi, K., \& Martinopoulos, G. (2015). Numerical Simulation of LNG Evaporation Inside Semi-Trailer Trucks Used for the Transportation of LNG to Small Scale Terminals and Refueling Stations. 8th GRACM International Congress on Computational Mechanics, (July).

20) Budiyanto, M.A., Shinoda, T., Nasruddin, Study on the CFD simulation of refrigerated container, (2017) IOP Conference Series: Materials Science and Engineering 257(1),012042

21) Incropera, F. P., Bergman, T. L., Lavine, A. S., \& DeWitt, D. P. (2011). Fundamentals of Heat and Mass Transfer. John Wiley \& Sons; 6th edition (March 10, 2006)

22) PT Pertamina (Persero). (2016). Roadmap Pembangunan Infrastruktur LNG untuk Transportasi Laut. Bandung.

23) Çengel, Y. A., \& Ghajar, A. J. (2014). Heat and Mass Transfer A Practical Approach. (5th ed.). New York: McGraw-Hill Education. https://doi.org/10.1017/CBO9780511676420.004

24) Adom, E., Islam, S. Z., \& Ji, X. (2010). Modelling of Boil-off Gas in LNG tanks: A case study. International Journal of Engineering and Technology, 2(4), 292-296.

25) PT Perusahaan Gas Negara (Persero). (2016). Pemanfaatan Energi Gas untuk Transportasi Laut. Bandung.

26) Budiyanto, A., Sugiarto, B., Anang, B., Multidimensional CFD simulation of a diesel engine combustion: A comparison of combustion models (2013) Lecture Notes in Electrical Engineering 190 LNEE(VOL. 2), pp. 879-893 